Umbi non Spesifik Madura (2): Etnobotani Tekkay (Eleocharis dulcis) pada Ekosistem Sawah Rawa sebagai Bahan Pangan di Pulau Madura

\title{
Eko Setiawan
}

\author{
Agrotechnology Department, Faculty of Agriculture, University of Trunojoyo Madura \\ e_setiawan@trunojoyo.ac.id
}

Abstrak

Tekkay (Eleocharis dulcis) mempunyai potensi sebagai pangan alternatif dari umbinya. Penelitian ini bertujuan mengumpulkan data lokasi tanaman tekkay sebagai bagian dari upaya penyelamatan plasma nutfah umbi-umbian untuk mendukung pertanian berkelanjutan dan ketersediaan pangan alternatif di Madura. Metode penelitian adalah eksplorasi dan observasi tempat tumbuh tanaman tekkay di Pulau Madura pada bulan Juli-Agustus 2016. Penelitian etnobotani tumbuhan tekkay dilakukan di Pulau Madura dengan metode wawancara open-ended, observasi di lapangan, dan purposive sampling. Tanaman Tekkay ternyata masih belum banyak dikenal oleh masyarakat, demikian juga pemanfaatannya. Tumbuhan ini memiliki nama daerah yang berbeda, di Madura dikenal dengan "Lhok colo'an", "Komis", dan "tekkay". Masyarakat Sumenep telah memanfaatkan umbinya untuk keripik atau emping. Daunnya juga dimanfaatkan sebagai pakan ternak. Di lokasi penelitian, jenis tekkay ini pada umumnya masih banyak tumbuh liar di rawarawa tepi pantai Bangkalan.

Kata kunci: etnobotani, Eleocharis dulcis, pangan pokok, Madura

Ethnobotany of Chinese Water Chestnut (Eleocharis dulcis) in Swamp Land

Rice Field Ecosystem as Food Material in Madura Island

\begin{abstract}
Chinese water chestnut (Eleocharis dulcis) or tekkay has the potential as food alternative source from its tubers. The objective of this study was to collect information of tekkay to make conservation biodiversity of tuber and food alternative in Madura. The exploration research was conducted using tekkay grown in Madura Island district during July to August, 2016. Ethno botanical study of tekkay in this research is conducted in Madura Island using openended interview methods, field observations, and purposive sampling. Tekkay is still neither much known nor utilized by the local people. The plant has different local names in Madura, such as "Lhok colo'an", "Komis", and "tekkay". In Sumenep district, local people use tuber of the species to make chips. The leaves are also used as livestock feed. In the research locations, the species is commonly grown in wild.
\end{abstract}

Keywords: ethnobotany, Eleocharis dulcis, staple food, Madura 


\section{PENDAHULUAN}

Indonesia adalah negara kepulauan yang memiliki cakupan luas yang bervariasi, dimana di dalamnya hidup flora, fauna dan mikroba yang sangat beranekaragam. Masyarakat lokal di perdesaan yang jauh dari perkotaan umumnya kaya sumber pengetahuan tradisional serta sedikit mendapat pengaruh intervensi kebudayaan luar tentu akan berdampak pada budaya, pola hidup, dan kelestarian sumberdaya alam hayati (Rahayu et al., 2008). Sehubungan semakin pentingnya peran etnobotani dalam mengungkapkan berbagai jenis tumbuhan berguna, terdapat tendensi ke arah kepentingan komersial. Etnobotani merupakan bidang ilmu yang cakupannya interdisipliner mempelajari hubungan timbal balik antara manusia dengan sumberdaya alam tumbuhan dan lingkungannya. Peran dan penerapan data etnobotani memiliki dua keuntungan yaitu keutungan ekonomi dan keuntungan dalam pengembangan dan konservasi sumber daya alam hayati. Keuntungan ekonomi ditunjukkan oleh peran penelitian etnobotani masa kini yang dapat mengidentifikasi jenis-jenis tumbuhan yang memiliki potensi ekonomi (Davis and Bye, 1982). Keuntungan lainnya adalah pengungkapan sistem pengelolaan sumberdaya alam lingkungan secara tradisional mempunyai andil yang penting dalam program konservasi; penerapan teknik tradisional dalam mengkonservasi jenis-jenis khusus dan habitat yang mudah rusak serta konservasi tradisional plasma nutfah tanaman budidaya guna program pemuliaan masa datang (Ruiz-Mallén et al., 2012; Davis and Bye, 1982).

Secara geografi Madura adalah bagian dari wilayah propinsi Jawa Timur, tetapi Madura adalah satu wilayah budaya yang berbeda dengan Jawa. Pulau Madura dikenal dengan sejumlah sebutan seperti Pulau Garam, Penghasil Jagung, Karapan Sapi, Ramuan Madura, Tanaman Tembakau, Daerah Tandus dan Panas. Daerah tandus dan panas selalu dikumandangkan dan selalu dibayangkan oleh kebanyakan orang tentang kondisi geografis pulau Madura. Pulau Madura yang beriklim kering dan bertanah kapur menurut Rifai (2013) tanahnya mempunyai derajad kesuburan yang rendah akan menghasilkan tutupan vegetasi tanaman yang berwanda khas karena bernuansa kegersangan. Tanaman yang muncul dari lahan yang gersang tersebut secara alamiah ada citra keindahan tersendiri.

Madura juga dikenal sebagai penghasil keripik tekkay, yang dalam bahasa Madura disebut Lhok colo'an adalah salah satu tumbuhan liar yang banyak terdapat di lahan rawa pasang surut sulfat masam. Tekkay dapat ditemukan di daerah terbuka di lahan rawa yang tergenang air, pada ketinggian $0-1350 \mathrm{~m}$ di atas 
permukaan laut. Tumbuhan ini juga banyak ditemui di daerah persawahan dan tergenang air; merupakan tanaman asli Asia Timur banyak ditanam di kolam daratan China (Marton, 1988). Tekkay dapat tumbuh baik pada suhu $\quad 30-35^{\circ} \mathrm{C}, \quad$ dengan kelembapan tanah 98-100\%. Tanah yang cocok untuk pertumbuhan tekkay adalah tanah lempung atau humus dengan $\mathrm{pH}$ 6.9-7.3, tetapi juga mampu tumbuh dengan baik pada tanah masam (Flach dan Rumawas, 1996). Tumbuhan sejenis rumput ini mempunyai rimpang pendek dengan stolon memanjang berujung bulat gepeng, berwarna kecoklatan sampai hitam. Tekkay adalah tumbuhan liar yang dapat beradaptasi dengan baik pada lahan rawa pasang surut sulfat masam dan mampu mengkelat logam berat (You et al., 2007); tanaman ini berpotensi sebagai peghasil pati di Madura selain tacca (Setiawan, 2016). Tumbuhan ini memiliki banyak manfaat salah satunya sebagai bahan keripik atau emping. Penelitian ini selain bertujuan untuk mengetahui kearifan pengetahuan masyarakat setempat mengenai pemanfaatan tanaman tekkay, juga untuk mengumpulkan data lokasi tanaman tekkay sebagai bagian dari upaya penyelamatan plasma nutfah umbi-umbian untuk mendukung pertanian berkelanjutan dan ketersediaan pangan alternatif di Madura.

\section{BAHAN DAN METODE}

Pemilihan lokasi penelitian didasarkan atas informasi koleksi herbarium yang tersimpan di Herbarium Bogoriense. Sebelum dilaksanakan penelitian ke lokasi, dilakukan penyebaran foto tekkay untuk mengetahui keberadaannya. Lokasi penelitian etnobotani tekkay (Eleocharis dulcis) di Kabupaten Bangkalan dan Sumenep, Madura. Penelitian dilakukan pada musim kemarau dimana umbi tekkay tersedia yaitu bulan Juli-Agustus 2016. Mata pencaharian utama penduduk Madura adalah bertani padi sawah (lahan tadah hujan dan sebagian sawah rawa) serta peternak sapi Madura. Pengambilan data dilakukan melalui pengamatan langsung dan wawancara dengan masyarakat lokal khususnya tentang tanaman tekkay. Partisipasi langsung dalam kehidupan masyarakat merupakan cara yang sangat esensial untuk memperoleh berbagai informasi yang diperlukan. Cara pendekatan ini penting untuk mengetahui lebih jauh tentang pengelolaan dan proses pemanfaatannya. Untuk memperoleh informasi tersebut dilakukan wawancara open-ended, bebas, observasi langsung di lapangan dan purposive sampling (keberadaan tumbuhan) dengan subyek beberapa informan yang meliputi pembuat keripik tekkay, pencari pakan sapi, dan tokoh adat di sekitar tanaman tekkay berada. Data yang dicatat mencakup keberadaan dan kepemilikan 
tanaman tekkay di lapangan, proses pembuatan keripik tekkay, dan aspek sosial-ekonomi produk keripik tekkay tersebut bagi masyarakat setempat.

\section{HASIL DAN PEMBAHASAN}

Selain kaya sumber daya alam, Indonesia juga memiliki keanekaragaman kelompok etnis dengan kehidupan sosial dan budaya yang berbeda. Berkaitan dengan kekayaan sumber daya alam yang akan menumbuhkembangkan berbagai sistem pengetahuan tentang alam dan lingkungan. Pengetahuan ini bervariasi bergantung pada tipe ekosistem tempat mereka tinggal, iklim terutama curah hujan, adat, tata cara, perilaku, pola hidup kelompok atau singkatnya pada tingkat kebudayaan suku-suku bangsa tersebut (Walujo, 2008). Menurut Rifai (2008), pada dasarnya masalah-masalah yang terkait dengan potensi lokal Madura berkaitan dengan persoalan subsistensi dan sintasan (survival) yang mampu menciptakan kekayaan (wealth creation) untuk kemakmuran. Tanaman tekkay ditemukan tumbuh liar di beberapa lokasi yang sudah disebutkan pada koordinat di atas dan masih dibiarkan tumbuh liar diantaranya di rawa pinggir pantai.

Pengembangan ekonomi memiliki keuntungan ditingkat nasional dan global meliputi prospek dari keanekaragaman hayati secara langsung kepada masyarakat lokal. Sedangkan keuntungan secara lokal mencakup aspek pendapatan yang berasal dari sumber daya tumbuhan terbarukan dan pemeliharaan serta perbaikan produksi yang disesuaikan dengan kondisi lingkungan lokal. Konservasi sumber daya alam hayati memiliki keuntungan secara nasional meliputi konservasi habitat untuk keanekaragaman hayati dan lingkungan serta konservasi keanekaragaman plasma nutfah untuk program pemuliaan tanaman berpotensi ekonorni (Davis and Bye, 1982). Sedangkan keuntungan secara lokal antara lain: konservasi dan pengakuan pengetahuan lokal konservasi keanekaragaman jenis dan habitat secara tradisional. Penelitian etnobotani mampu mengungkapkan pemanfaaian berbagai jenis sumber daya alam tumbuhan secara tradisisnal oleh masyarakat setempat. Pengungkapan potensi sumber daya alam tumbuhan merupakan titik awal pengembangannya menjadi jenis unggulan yang bermanfaat bagi kepentingan masyarakat banyak (Ruiz-Mallén et al., 2012; Davis and Bye, 1982).

Upaya mengenalkan tanaman tekkay sebagai tanaman potensial dan fungsional menggantikan ketergantungan terhadap beras dianggap tepat terutama di lingkungan Madura, yang sebagian besar lahan pertaniannya bergantung hujan. Diharapkan produk dari tekkay 
dan tacca tersebut mampu menjadi sumber pangan alternatif substitusi beras demi terwujudnya kemandirian dan ketahanan pangan nasional (Setiawan, 2016).

\section{Pola Sebaran Tekkay}

Telah banyak dipublikasikan Pulau Madura mempunyai iklim kering, tanah berkapur dengan derajat kesuburan rendah sehingga mempunyai vegetasi tanaman yang khas (Rifai, 2007). Ciri khas tanaman yang ada di Pulau Madura terkait erat dengan budaya dan perilaku keseharian masyarakat, termasuk dalam usaha penyediaan pangan, penataan lingkungan tinggal dan kegiatan pertanian. Dari laporan diketahui bahwa tanaman tekkay biasa hidup di daerah rawa pasang surut (Asikin dan Thamrin, 2012). Namun demikian pola sebaran dan ekologi tekkay di Kabupaten Bangkalan dan Sumenep belum ada laporan.

Dari penelitian ini diketahui bahwa tanaman tekkay banyak tumbuh di daerah rawa yang berada di selatan dan barat dari Kabupaten Bangkalan. Tanaman tekkay di Kecamatan Kwanyar jenis komis (E. philippinensis dan $E$. geniculata) terdapat di dua tempat yaitu pada titik koordinat $79^{\circ}$ 25.32752" LS, 112 ${ }^{\circ} 51^{\prime} 38.05946^{\prime \prime}$ BT pada ketinggian $46.62 \mathrm{~m}$ dpl. dan pada koordinat $7^{\circ} 10^{\prime} 19.7707^{\prime \prime}$ LS, 112 $53^{\prime} 20.78399^{\prime \prime}$ BT dengan ketinggian $25.84 \mathrm{~m}$ dpl. (Tabel 1). Lokasi tumbuh tanaman tekkay di Kecamatan Kamal paling banyak di
Desa Telang yang berada pada 6 tempat, masing-masing berada pada titik koordinat: $7^{0} 7^{\prime} 11.02982$ " LS, 112042' 37.95648" BT; $7^{\circ} 7^{\prime}$ 10.52224" LS, 112 ${ }^{\circ} 42^{\prime} 45.02014$ " BT; $77^{\prime}$ 11.31614" LS, $112^{\circ} 42^{\prime}$ 36.36567" BT; 707' 10.20395" LS, $112^{\circ} 42^{\prime} 35.25659^{\prime \prime}$ BT; 707' 6.86089" LS, 112042' 42.2873" BT; dan 707' 8.81817" LS, $112^{\circ} 42^{\prime} 42.03957^{\prime \prime}$ BT dengan ketinggian antara 18.25 $36.86 \mathrm{~m}$ dpl. Di Telang ditemukan 3 jenis tekkay yaitu E. spiralis (Telenteyan), E. geniculata (Komis), dan E. dulcis (Lhok colo'an). Di Kecamatan Kamal, selain di Desa Telang, tekkay juga ditemukan di Desa Gili Anyar yang berada pada titik koordinat: $7^{\circ} 7^{\prime}$ 42.72032" LS, $112^{\circ} 42^{\prime} 45.02014$ " BT yang berada di ketinggian $35.68 \mathrm{~m}$ dpl. dengan jenis tekkay E. dulcis (Lhok colo'an) dan E. retroflexa (Komis).

Sebaran tanaman tekkay di Kecamatan Socah ada di Desa Dak Kiring yang berada pada koordinat 704' 18.46312" LS, $112^{\circ} 40^{\prime} 47.45686^{\prime \prime}$ BT pada ketinggian tempat $21.94 \mathrm{~m} \mathrm{dpl}$ dengan jenis tekkay E. dulcis (Lhok colo'an) dan E. geniculata (Komis). Selain itu juga terdapat di Desa Ujung Piring Timur yang berada pada titik koordinat $7^{\circ} 5^{\prime} 4.7879$ " LS, $112^{\circ} 41^{\prime}$ 56.94233" BT pada ketinggian tempat $42.02 \mathrm{~m}$ dpl. hanya ditemukan jenis tekkay $E$. geniculata (Komis).

Di wilayah Kecamatan Bangkalan banyak ditemukan tanaman tekkay terutama di dekat perumahan yang diduga semula merupakan daerah rawa-rawa 
yang ditimbun dan selanjutnya dibangun perumahan. $\mathrm{Di}$ jalan Kinabalu yang berada pada titik koordinat 703' 10.78119" LS, $112^{\circ} 43^{\prime} 39.96777^{\prime \prime}$ BT pada ketinggian tempat $58.40 \mathrm{~m}$ dpl. ditemukan jenis E. dulcis (Lhok colo'an). Di Perumahan Green Asri yang berada pada titik koordinat 7०3' 11.23973" LS, 112043'
34.76543" BT pada ketinggian $37.66 \mathrm{~m}$ dpl. ditemukan jenis $E$. spiralis (Telenteyan).

Perumahan Nilam yang berada pada titik koordinat $7^{\circ} 2^{\prime} 52.25257^{\prime \prime}$ LS, $112^{\circ} 44^{\prime} 35.36879^{\prime \prime}$ BT pada ketinggian $33.15 \mathrm{~m}$ dpl. ditemukan 2 jenis tekkay E. dulcis (Lhok colo'an) dan E. geniculata (Komis).

Tabel 1. Lokasi tanaman tekkay di Kabupaten Bangkalan

\begin{tabular}{|c|c|c|c|}
\hline Lokasi & Titik koordinat & $\begin{array}{l}\text { Ketinggian } \\
\text { (m dpl.) }\end{array}$ & $\begin{array}{c}\text { Jenis tekkay yang } \\
\text { ditemukan - Nama } \\
\text { daerah }\end{array}$ \\
\hline \multirow{2}{*}{ Kwanyar } & $\begin{array}{l}7^{\circ} 9^{\prime} 25.32752^{\prime \prime} \mathrm{S} \\
112^{\circ} 51^{\prime} 38.05946^{\prime \prime} \mathrm{E}\end{array}$ & 46.62 & $\begin{array}{l}\text { E. philippinensis (Komis) } \\
\text { E. geniculata (Komis) }\end{array}$ \\
\hline & $\begin{array}{l}7^{\circ} 10^{\prime} 19.7707 " \mathrm{~S} \\
112^{\circ} 53^{\prime} 20.78399^{\prime \prime} \mathrm{E}\end{array}$ & 25.84 & E. geniculata (Komis) \\
\hline $\begin{array}{l}\text { Desa Gili Anyar, Kec. } \\
\text { Kamal }\end{array}$ & $\begin{array}{l}7^{\circ} 7^{\prime} 42.72032^{\prime \prime} \mathrm{S} \\
112^{\circ} 42^{\prime} 45.02014 \text { " E }\end{array}$ & 35.68 & $\begin{array}{l}\text { E. dulcis (Lhok colo'an) } \\
\text { E. retroflexa (Komis) }\end{array}$ \\
\hline \multirow{5}{*}{ Desa Telang, Kec. Kamal } & $\begin{array}{l}7^{0} 7^{\prime} 11.02982^{\prime \prime} \mathrm{S} \\
112^{\circ} 42^{\prime} 37.95648^{\prime \prime} \mathrm{E} \\
7^{\circ} 7^{\prime} 10.52224^{\prime \prime} \mathrm{S} \\
112^{\circ} 42^{\prime} 45.02014^{\prime \prime} \mathrm{E}\end{array}$ & 22.23 & $\begin{array}{l}\text { E. geniculata (Komis) } \\
\text { E. dulcis (Lhok colo'an) }\end{array}$ \\
\hline & $\begin{array}{l}7^{\circ} 7^{\prime} 11.31614^{\prime \prime} \mathrm{S} \\
112^{\circ} 42^{\prime} 36.36567^{\prime \prime} \mathrm{E}\end{array}$ & 25.42 & $\begin{array}{l}\text { E. spiralis (Telenteyan) } \\
\text { E. geniculata (Komis) } \\
\text { E. dulcis (Lhok colo'an) }\end{array}$ \\
\hline & $\begin{array}{l}7^{\circ} 7^{\prime} 10.20395^{\prime \prime} \mathrm{S} \\
112^{\circ} 42^{\prime} 35.25659^{\prime \prime} \mathrm{E}\end{array}$ & 36.86 & E. geniculata (Komis) \\
\hline & $\begin{array}{l}7^{0} 7^{\prime} 6.86089 " \mathrm{~S} \\
112^{\circ} 42^{\prime} 42.2873^{\prime \prime} \mathrm{E}\end{array}$ & 18.25 & E. dulcis (Lhok colo'an) \\
\hline & $\begin{array}{l}7^{\circ} 7^{\prime} 8.81817^{\prime \prime} \mathrm{S} \\
112^{\circ} 42^{\prime} 42.03957^{\prime \prime} \mathrm{E}\end{array}$ & 31.39 & $\begin{array}{l}\text { E. dulcis (Lhok colo'an) } \\
\text { E. geniculata (Komis) }\end{array}$ \\
\hline $\begin{array}{l}\text { Desa Dak Kiring, Kec. } \\
\text { Socah }\end{array}$ & $\begin{array}{l}7^{\circ} 4^{\prime} 18.46312^{\prime \prime} \mathrm{S} \\
112^{\circ} 40^{\prime} 47.45686^{\prime \prime} \mathrm{E}\end{array}$ & 21.94 & $\begin{array}{l}\text { E. dulcis (Lhok colo'an) } \\
\text { E. geniculata (Komis) }\end{array}$ \\
\hline Ujung Piring Timur & $\begin{array}{l}7^{\circ} 5^{\prime} 4.7879 " \mathrm{~S} \\
112^{\circ} 41^{\prime} 56.94233^{\prime \prime} \mathrm{E}\end{array}$ & 42.02 & E. geniculata (Komis) \\
\hline $\begin{array}{l}\text { Jl. Kinibalu Kec. } \\
\text { Bangkalan }\end{array}$ & $\begin{array}{l}7^{\circ} 3^{\prime} 10.78119^{\prime \prime} \mathrm{S} \\
112^{\circ} 43^{\prime} 39.96777^{\prime \prime} \mathrm{E}\end{array}$ & 58.40 & E. dulcis (Lhok colo'an) \\
\hline Perumahan Green Asri & $\begin{array}{l}7^{\circ} 3^{\prime} 11.23973^{\prime \prime} \mathrm{S} \\
112^{\circ} 43^{\prime} 34.76543^{\prime \prime} \mathrm{E}\end{array}$ & 37.66 & E. spiralis (Telenteyan) \\
\hline $\begin{array}{l}\text { Perumahan Nilam } \\
\text { Bangkalan }\end{array}$ & $\begin{array}{l}7^{\circ} 2^{\prime} 52.25257^{\prime \prime} \mathrm{S} \\
112^{\circ} 44^{\prime} 35.36879^{\prime \prime} \mathrm{E}\end{array}$ & 33.15 & $\begin{array}{l}\text { E. dulcis (Lhok colo'an) } \\
\text { E. geniculata (Komis) }\end{array}$ \\
\hline Desa Kramat & $\begin{array}{l}7^{\circ} 2^{\prime} 29.79499^{\prime \prime} \mathrm{S} \\
112^{\circ} 42^{\prime} 21.04688^{\prime \prime} \mathrm{E}\end{array}$ & 26.64 & $\begin{array}{l}\text { E. spiralis (Telenteyan) } \\
\text { E. dulcis (Lhok colo'an) }\end{array}$ \\
\hline Desa Sembilangan & $\begin{array}{l}7^{\circ} 2^{\prime} 34.27535^{\prime \prime} \mathrm{S} \\
112^{\circ} 41^{\prime} 30.81838^{\prime \prime} \mathrm{E}\end{array}$ & 19.10 & $\begin{array}{l}\text { E. dulcis (Tekkay } \\
\text { grobog) } \\
\text { E. spiralis (Telenteyan) }\end{array}$ \\
\hline Bancaran & $\begin{array}{l}7^{\circ} 0^{\prime} 9.76542^{\prime \prime} \mathrm{S} \\
112^{\circ} 46^{\prime} 21.71778 " \mathrm{E}\end{array}$ & 45.76 & E. dulcis (Lhok colo'an) \\
\hline Sabiyan & $\begin{array}{l}6^{\circ} 59^{\prime} 47.50712^{\prime \prime} \mathrm{S} \\
112^{\circ} 46^{\prime} 46.72695^{\prime \prime} \mathrm{E}\end{array}$ & 40.27 & $\begin{array}{l}\text { E. dulcis (Lhok colo'an) } \\
\text { E. geniculata (Komis) }\end{array}$ \\
\hline
\end{tabular}


Sedangkan di Desa Kramat yang berada pada titik koordinat 702' 29.79499" LS, 112 ${ }^{\circ} 42^{\prime}$ 21.04688" BT dengan ketinggan tempat $26.64 \mathrm{~m}$ dpl. ditemukan 2 jenis tekkay E. spiralis (Telenteyan), dan E. dulcis (Lhok colo'an). Sedangkan di Desa Sembilangan yang berada pada titik koordinat 702' 34.27535" LS, 112 ${ }^{\circ} 41^{\prime}$ 30.81838 " BT dengan ketinggian tempat $19.10 \mathrm{~m}$ dpl. ditemukan 2 jenis tekkay E. dulcis (tekkay grobog), dan E. spiralis (Telenteyan). Di Desa Bancaran yang berada pada titik koordinat $7^{\circ} 0^{\prime} 9.76542^{\prime \prime}$ LS, 112046' 21.71778' BT di ketinggian $45.76 \mathrm{~m}$ dpl. hanya ditemukan tekkay jenis $E$. dulcis (Lhok colo'an). Lokasi tanaman di Desa Sabiyan berada pada koordinat 6059' 47.50712" LS, $112^{\circ} 46^{\prime}$ 46.72695" BT pada ketinggian tempat $40.27 \mathrm{~m}$ dpl. ditemukan 2 jenis tekkay E. dulcis (Lhok colo'an), dan E. geniculata (Komis).

Tumbuhan tekkay di Kabupaten Bangkalan jarang dimanfaatkan, tanaman hanya dimanfaatkan untuk pakan ternak. Batang tanaman tekkay di Indonesia umumnya dipakai sebagai pakan kerbau (Asikin dan Thamrin, 2012). Pada areal rawarawa yang ditumbuhi oleh tanaman tekkay, mayoritas hanya ditumbuhi oleh tanaman tekkay saja. Karena tanaman ini mampu bertahan hidup meskipun pada musim kemarau, dan selama umbi rimpangnya masih ada di dalam tanah maka tanaman akan tumbuh terus meskipun disabit berulangulang. Pada musim penghujan selain tanaman tekkay juga tumbuh beberapa jenis rumput lainnya yang digunakan sebagai pakan ternak, diantaranya tanaman kangkung air. Tanaman tekkay di kabupaten Bangkalan masih dimanfaatkan sebatas pada pakan ternak, belum ada kegiatan pengambilan umbi tekkay seperti di Kabupaten Sumenep. Para pencari umbi tekkay di Kabupaten Sumenep hanya mencari umbi tekkay di Sumenep saja, alasannya adalah umbi tekkay asal Sumenep rasanya lebih manis dibandingkan umbi asal Bangkalan. $\mathrm{Di}$ daerah Sampang dan Pamekasan sangat jarang ditemukan tanaman tekkay.

Kegiatan mencari takay untuk pakan ternak dapat dilihat pada Gambar 1 A-C, yaitu hamparan tanaman tekkay yang tumbuh di rawa-rawa bekas disabit. Terlihat ada tanda kepemilikan rumput tekkay yang disebut takur. Takur terbuat dari ranting yang ditancapkan di tanah kemudian di ujungnya dililiti daun pisang atau platik atau rumput yang diikatkan di ranting sebagai tanda kepemilikan wilayah atau area merumput. Dengan diberi tanda takur berarti tanaman tersebut ada yang merawat. Biasanya \pm 20 hari setelah disabit, tanaman tekkay diberi pupuk urea dengan cara menyebarkan ke lahan yang menjadi wilayah petani yang meawatnya. Dengan pemberian tanda takur maka petani lain yang 
tidak merawat tanaman tersebut tidak berani untuk mengambil tanaman tekkay di wilayah yang dikasih tanda. Cara ini memberikan solusi untuk tidak berebut lahan tekkay sebagai sumber pakan ternak. Mengingat pada musim kering tanaman tekkay yang tumbuh menghijau di rawa-rawa merupakan sumber utama pakan ternak dan menjadi tujuan pertama dari para pencari rumput. Jika wilayah yang ada tanda takur tersebut tidak dirawat selama 1-2 bulan, dibiarkan oleh petani yang merawat sebelumnya, maka wilayah tersebut bebas untuk diambil oleh para pencari rumput. Tidak semua daerah rawa-rawa yang ada tanaman tekkay diberi tanda takur. Para pencari rumput sudah hafal dengan beberapa daerah rawa yang ditumbuhi tanaman tekkay seperti tertera pada Tabel 1 di atas. Mereka secara rutin akan berganti tujuan menyabit rumput dari daerah $1 \mathrm{ke}$ daerah lainnya sesuai dengan kebiasaan para pencari rumput. Terdapat perbedaan kebiasaan penetuan tujan wilayah mencari rumput antara perumput satu dengan lainnya. Selama musim musim kemarau areal tanaman tekkay merupakan tujuan utama para pencari rumput, tetapi jika musim hujan alternatif lokasi merumput lebih banyak tersedia, sehingga kegiatan pencarian rumput pakan ternak tidak hanya terkonsentrasi pada areal tanaman tekkay yang ada di rawa-rawa. Ini merupakan manajemen pengelolaan lahan rumput sebagai pakan ternak bagi peternak sapi madura. Areal tanaman tekkay di rawa-rawa kebanyakan untuk pakan sapi, tetapi pada musim kemarau peternak kambing dan domba juga ikut mencari tekkay akibat keterbatasan tanaman hijauan pakan ternak yang lain.
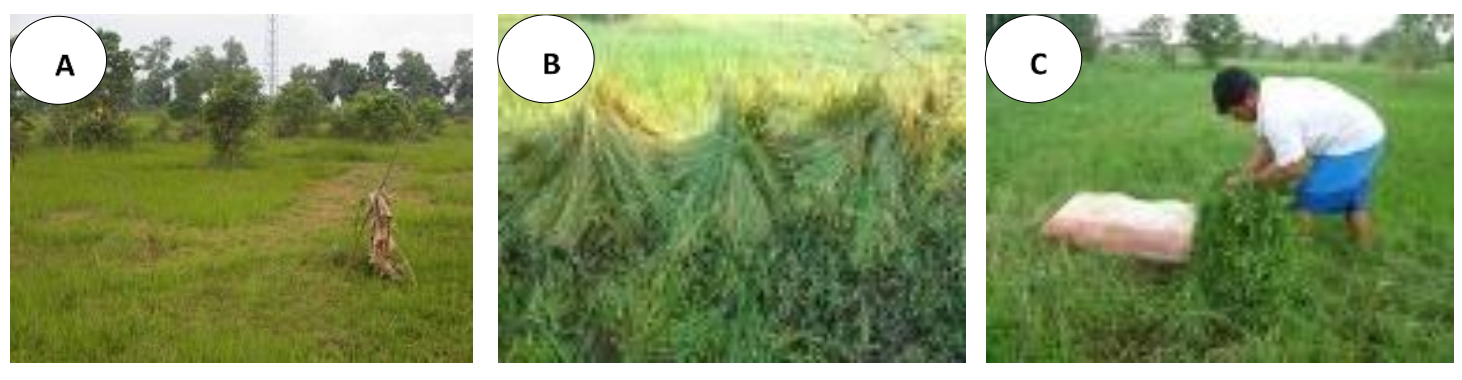

Gambar 1. Pemanfaatan tanaman tekkay di Kabupaten Bangkalan sebagai pakan ternak. (A) hamparan tanaman tekai di rawa-rawa Desa Telang dengan tanda takur sebagai wilayah kepemilikan tanaman tekkay untuk pakan ternak, (B) tanaman tekkay yang disabit dan dikumpulkan, (C) pencari pakan ternak sedang menggumpulkan tanaman tekkay dan dimasukkan ke karung plastik. 
Tekkay, untuk dikonsumsi melalui proses tertentu seperti yang terlihat pada Gambar 2. Ibuibu di Kabupaten Sumenep secara berkelompok 6-8 orang mencari umbi tekkay sebagai pekerjaan sampingan, biasanya di musim kemarau (Juli-Agustus). Lokasi tanaman tekkay di kabupaten Sumenep yang diambil umbinya terkonsentrasi di tiga wilayah yaitu Marengan, Pabiyan, dan Kalimook. Bahan baku umbi tekkay ada di Dusun Brambag Kalimook dan daerah Astagumuk dekat Bandara Trunojoyo. Pencari umbi tekkay berangkat pagi dengan membawa ember dan linggis kecil sebagai alat untuk mencungkil tanah. Tanah dipilah-pilah untuk diambil umbi tekkay-nya. Kegiatan mencari umbi tekkay berlangsung dari jam sampai sekitar jam 12 siang, biasanya setiap orang mendapatkan umbi sebanyak \pm $0.25 \mathrm{~kg}$. Umbi tekkay yang diperoleh biasanya langsung diproses menjadi keripik atau emping pada hari yang sama (jarang menyimpan sampai banyak). Cara pengolahan umbi tekkay yaitu diawali dengan mencuci umbi sampai bersih kemudian dikupas menggunakan pisau runcing (karena kulitnya tipis dan ukuran umbi cukup kecil). Umbi dicuci lagi dengan air mengalir lalu disangrai di hanangan atau tempayan tanah liat selama 5 menit. Jika terlalu lama perlakuan sangrainya maka umbi akan gosong dan keras sehingga tidak bisa dipipinkan untuk menjadi emping. Setelah itu beberapa umbi (biasanya 7-11 umbi) dipipihkan "di-teteh" ditumbuk menggunakan alu sampai terbentuk keripik atau emping tekkay. Keripik atau emping tekkay yang sudah jadi kemudian dijemur selama 1 hari, kemudian disimpan. Untuk memproduksi $1 \mathrm{~kg}$ keripik atau emping dibutuhkan waktu satu minggu. Pembuat keripik biasanya sesegera mungkin menjual produknya untuk menghindari keruskan produk. Keripik atau emping tekkay yang terlalu lama disimpan akan banyak bubuk putih (pati dari umbi kemungkinan terpisah-pisah), biasa diatasi dengan cara menjemur di bawah sinar matahari langsung. Produsen keripik atau emping tekkay menjual produknya ke toko-toko China yang ada di kota Sumenep seperti: Rumah Makan 17 Agustus, Toko Subur, Toko Mamamia di Jl. Seludang, Sumenep. Di Bangkalan yang menjual keripik atau emping tekkay ada di Toko Nusa Indah. Produk kripik dijual dengan cara membungkus dengan plastik, tidak ada pengemasan khusus maupun pelabelan serta pemberian nama produk. Harga $1 \mathrm{~kg}$ keripik atau emping tekkay mentah sebesar $\mathrm{Rp}$ 200.000,- sampai Rp. 250.000,-. Pelabelan dan pemberian nama dilakukan oleh pembeli dan biasanya dikemas dalam ukuran kecil sampai sedang (harga 100 gramsekitar Rp. 35.000,-). Dengan harga jual tersebut, umbi tekkay berpotensi ekonomi untuk dikembangkan dan dibudidayakan 

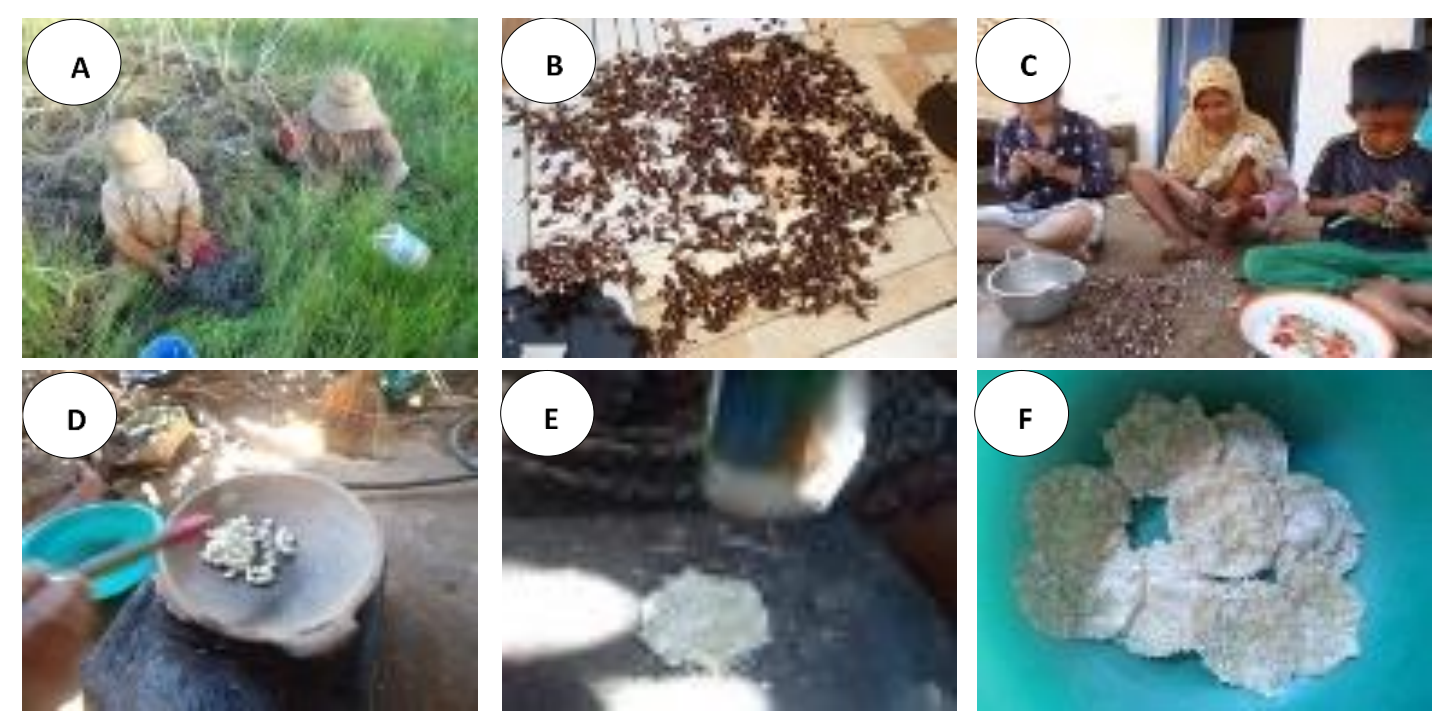

Gambar 2. Proses pembuatan keripik atau emping tekkay, (A) Ibu-ibu yang mencari umbi tekkay, (B) umbi tekkay dikeringanginkan sebelum di proses, (C) pengupasan kulit umbi tekkay, (D) umbi tekai yang sudah bersih digoreng sangrai selama 5 menit, (E) pemipihan umbi dengan menggunakan alu, dan (F) keripik atau empik tekkay yang sudah jadi

secara komersial. Ekstrak tekkay dilaporkan mengandung senyawa phenol yang bisa mencegah radikel bebas, dan mengandung asam askorbat serta butylated hydroxytoluene yang tinggi yang dikenal sebagai antioksidan (You et al., 2007).

\section{KESIMPULAN}

Perlu dilakukan antisipasi
terhadap pemanasan global
dengan menyiapkan bibit atau
benih baru yang tahan kering
sehingga mampu berproduksi
ketika iklim di Pulau Madura
semakin memanas. Untuk itu perlu
dilakukan kegiatan eksplorasi flora

yang berbasis kearifan lokal Madura untuk kepentingan pengembangan pangan pada masa mendatang.

\section{DAFTAR PUSTAKA}

Asikin, S., dan M. Thamrin. 2012. Manfaat Purun Tikus (Eleocharis dulcis) Pada Ekosistem Sawah Rawa. Jurnal Litbang Pertanian. 31(1): 35-42.

Davis, T., R.A. Bye. 1982. Ethnobotany and Progressive Domestication of Jaltomata (Solanaceae) in Mexico and Central America. Economic Botany, 36(2): 225-241 
Flach, M. and F. Rumawas. 1996. Plants yielding non-seed carbohydrates. Plant Resources of South-East Asia (PROSEA) 9: 97-100. http://www.prosea.org. [20 July 2008].

Marton, J.F. 1988. Chinese Waterchestnut in FloridaPast, Present, and Future. Proc. Fla. State Hort. Soc. 101: 139-144.

Rahayu, M., S. Sunarti, A.P. Keim. Kajian Etnobotani Pandan Samak (Pandanus odoratissimus L.f.): Pemanfaatan dan Peranannya dalam Usaha Menunjang Penghasilan Keluarga di Ujung Kulon, Banten. Biodiversitas. 9(4): 310-314.

Rifai, M.A. 2007. Memadurakan Pembangunan Madura. Makalah disampaikan dalam Musyawarah Besar III Masyarakat Madura. Surabaya, 26 Agustus 2007. 9 halaman.

Rifai, M.A. 2008. Urgensi Pengembangan Potensi Lokal Madura oleh Civitas Universitas Trunojoyo. Makalah disampaikan di Universitas Trunojoyo Madura. Bangkalan, 9 Juli 2008. 4 halaman.
Rifai, M.A. 2013. Memadurakan Pembangunan Madura dalam Seserpih Garam Madura. UTM Press. Bangkalan.

Ruiz-Mallén, I., P. Domínguez, L. Calvet-Mir, M. Orta Martinez, V. Reyes-García. 2012. Applied research in ethnoecology: Fieldwork experiences. Universitat Autònoma de Barcelona / ICREA. Pp.9-30.

Setiawan, E. Setiani. 2016. Potensi Tacca Sebagai Pangan Lokal Sumber Karbohidrat Untuk Mendukung Diversifikasi Konsumsi Pangan di Kabupaten Bangkalan. Prosiding Seminar Nasional Perhepi. UB.

Waluyo, E.B. 2008. REVIEW: Research Ethnobotany in Indonesia and the Future Perspectives. Biodiversitas. 9(1): 59-63.

You, Y., X. Duan, X. Wei, X. Su, M. Zhao, J. Sun, N. Ruenroengklin, Y. Jiang. Identification of Major Phenolic Compounds of Chinese Water Chestnut and their Antioxidant Activity. Molecules. 12: 842-852. 